\title{
GONDOLATOK A KÖZLEKEDÉS ÉS SZERVEZETI KAPCSOLATAI KÉRDÉSKÖRÉRŐL A BUDAPESTI TÉRSÉG KÖZIGAGATÁSI PROBLÉMÁINAK KAPCSÁN
}

\author{
(Ideas about the Question of Transportation and Its
} Organisational Connections in the Case of the Administrative Problems of Budapest Area)

\section{KOVÁCS RÓBERT}

Kulcsszavak:

Budapestiagglomeráció közlekedés közlekedés-politika

A szerzö tanulmányában közlekedési szakemberek munkáinak, fogalomrendszerének bázisán kívánja multidiszciplináris megvilágításba helyezni a budapesti agglomeráció közlekedésének problematikajat. Elemzi a fôváros és térsége közlekedésének, közlekedés-politikájának tényezöit, érdekeltségeit, elméleti és a térségre vonatkozó konkrét ismeretek ütköztetése révén a legfontosabb közlekedés-politikai konzek. venciák levonására törekszik.

„A kommunikációs technológiák fejlödése nyomán végbemenő gazdasági és politikai változások a várható tendenciák alapján a régi és új államhatárok gazdasági jelentöségét csökkentik. A létrejövö 'időintegrált' világrendszerben a kiterjedtté vált városi agglomerációs térségek nemzetközi kommunikációs hálózatok csomópontjai lesznek, és a korábbiakkal ellentétben nem csupán a környékük, illetve hátterïk központjai immár, hanem az országok közti, söt globális hatókörhöz is jutnak. Ez a hatókörnövekedés pedig, a fö közlekedési vonalakat vonzó hatásával, döntö mértékben befolyásolhatja az európai föhálózatok térszerkezetének alakulását, közvetetten pedig a regionális fejlódés differenciálódását."

(Mottó: Molnár 2000)

A szerző a budapesti agglomeráció szociológia-gazdasági aspektusaival foglalkozik, mindenekelött az önkormányzatokra koncentrálva (vö. pl. Kovács 1999). Az agglomeráció vizsgálatának egyik kiemelt kérdése a közlekedés, annak megoldatlansága, és a téma ismerői jól tudják, hogy az önkormányzatoknak kiemelt szerepük van a közlekedésben (városi tömegközlekedés, közútfejlesztés és -karbantartás stb.). A jelen tanulmány egy kísérlet. Közlekedési szakemberek munkáinak, fogalomrendszerének bázisán kívánja egy kicsit más, multidiszciplináris megvilágításba helyezni a budapesti agglomeráció közlekedésének problematikáját. Három részben tárgyalja a budapesti térség közlekedés gondjait, közlekedés-politikájának kérdéseit:

1) Elméleti kérdések: a vizsgált probléma legfontosabb dimenzióit emeli ki különböző szempontokból.

2) A budapesti térség problémái: a város közlekedésének, közlekedési politikájának tényezöit, azok érdekeltségeit elemzi. 
Tér és Társadalom 15. évf. 2001/3-4. 69-80. p.

3) Megoldási alternatívák: egyfajta ütköztetése kíván lenni az elméleti és a térségre vonatkozó konkrét ismereteknek, vagyis a közlekedés-politikai konzekvenciák levonására törekszik.

Bár látszólag feszes a tanulmány vonalvezetése, a valóság az, hogy ezt nagyon nehéz megoldani, mert nagyon sok a felvetett kérdés és nagyon sokféle válasz adható rájuk. A legfontosabb mind közül, hogy mekkora a szerepe a közlekedésnek a vizsgált térség esetében. Erre a kérdésre szakértők és politikusok egyaránt azt a választ adják, hogy nagy. Arra a kérdésre, hogy mi lehet a problémák megoldása még szintén egybehangzó a válasz: a Budapesti Közlekedési Szövetség. A szerző azt a kérdést igyekszik körüljárni, hogy amikor ekkora az összhang, akkor miért tart valami ennyi ideig!

\section{Elméleti és probléma-vázlat}

A városi agglomeráció, szuburbanizáció fogalomkörének meghatározásai kiemelt elemként tartalmazzák a közlekedési vonatkozásokat. Maga a szuburbanizációs folyamat a városnövekedés egy meghatározott szakasza (Berg et al. 1982; Enyedi 1988) (1. ábra). A városok növekedése pedig a termelés során alkalmazott technológia megkívánta népességkoncentráció, mint igény, és a közlekedési infrastruktúra és technológia fejlettsége, mint lehetőség, hogy ez a koncentráció egy szélesebb térségen belül, dekoncentráltan valósulhasson meg. A közvetítö médium a telekérték, amely gazdasági (megfizethetőség, profitabilitás) és társadalmi (ki mely övezetben képes letelepedni, hol élnek azok, akikhez tartozni akar) szempontok alapján rendezi be a teret.

Véleményưnk szerint a következök a probléma kiemelt dimenziói:

1) Jelenleg Magyarországon a legtöbb nagyváros (120 ezer lakosnál nagyobb városok) környékén határozott szuburbanizációs jelenségek figyelhetők meg. Ezzel párhuzamosan a többi megyei jogú város körül, többé-kevésbé erỏs népességnövekedést ${ }^{2}$ mutatnak a községek, kisebb települések (Kovács 1999), és más térségekben is megfigyelhetők hasonló jelenségek (Perczel 1996).

2) Tény, hogy a jelenség elemi ereje ellenére nincs felkészülve rá sem a közigazgatás, sem más szervezet (pl. a tömegközlekedést szolgáltatók).

3) Amellett tehát, hogy egy, a mai Magyarországot általánosan jellemző jelenségröl van szó, túlzás nélkül állítható, hogy a legizgalmasabb kérdések a budapesti térségben merülnek fel: itt a legkomplexebb az önkormányzati rendszer, vagy éppen a közlekedési rendszer.

4) Budapest közlekedési problémáit, közlekedési politikáját nem csupán az agglomeráció, hanem a város országos és nemzetközi szerepe, funkciói, versenyhelyzete is meghatározza. 
Tér és Társadalom 15. évf. 2001/3-4. 69-80. p.

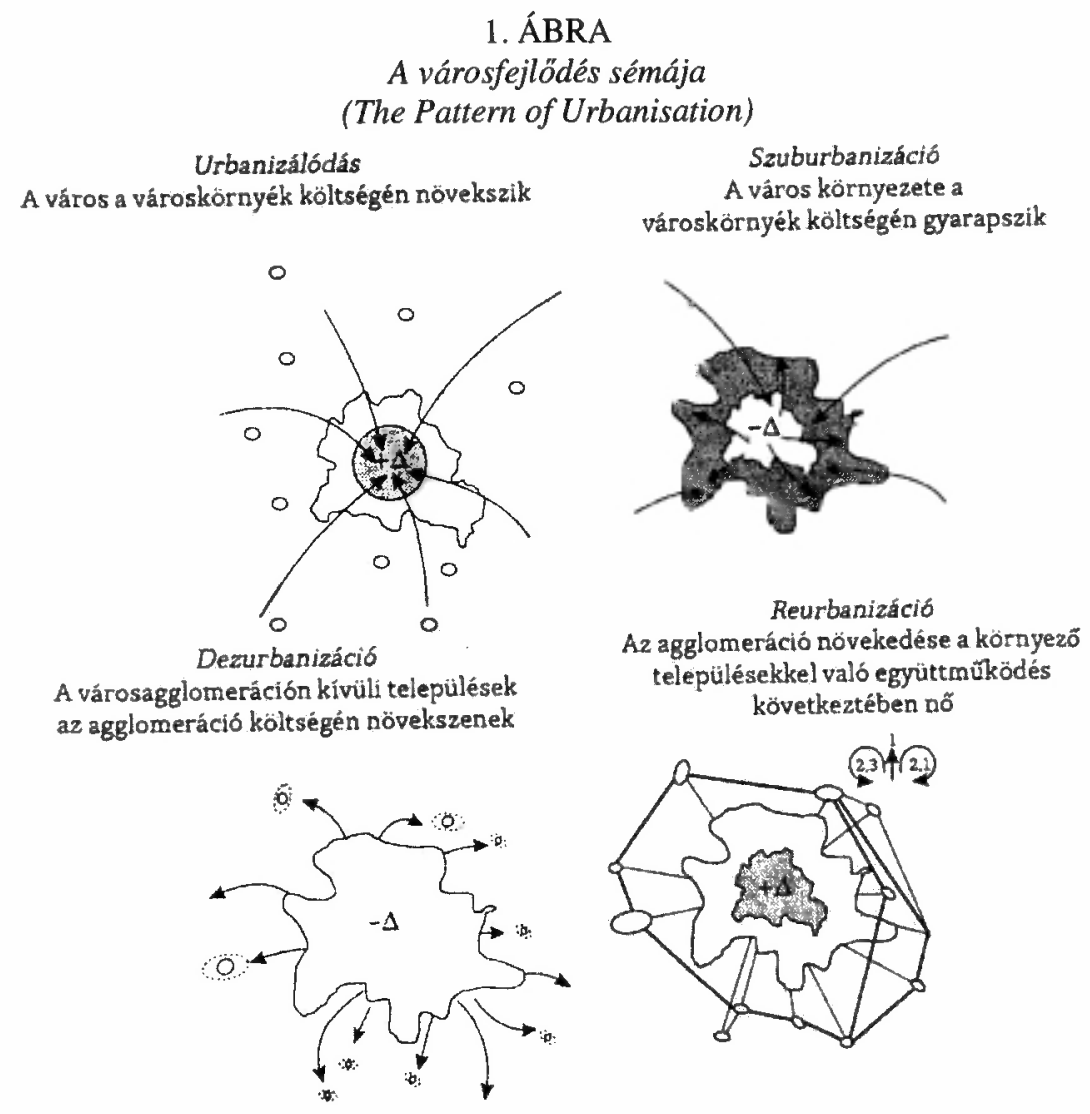

Forrás: Mándoki 2000.

A településszerkezet dekoncentráciojának fontos hatása a közlekedési szükséglet növekedése, amely egyúttal maga is visszahat a települési feltételekre. A szuburbanizáció kapcsán jelentkező problémák általunk történt egyik elsỏ megfogalmazásában éppen arra a kérdésre koncentráltunk, hogy a szuburbanizációs elönyők és hátrányok mennyire ugyanazokat a személyeket érintik, és mekkora a késleltetés a hátrányok jelentkezésében. A megelőlegezett válasz az volt, hogy az elönyök rövid távon jelentkeznek az egyén szintjén, a költségek ugyanakkor gyorsabban jelentkeznek társadalmi szinten és csak később az egyes egyénekében ${ }^{3}$. Kicsit világosabban a klasszikus szuburbanizációs képlet szerint a nagyvárosból kiköltözỏ (felső)középosztály nem elsősorban a megfizethetőbb otthont, hanem a jobb életfeltételeket keresi. Amikor azonban a kiköltözésük tömegessé válik, ismét romlanak a feltételek. A zöldövezeti otthon megközelítésének időtartama megnő, az idő nagyobb részét mind rosszabb minöségủ környezetben kell eltölteni, és végeredményben mind költségesebbé válik az új életforma. Christopher Zegras (Zegras 2000) a makroszintủ problémák vizsgálatakor is a fenti tényezóket elemzi, mint a modern, dekoncentrálódó város közlekedésének legfontosabb makroszintủ hatásait: költsé- 
Kovács Róbert : Gondolatok a közlekedés és szervezeti kapcsolatai kérdésköréröl a budapesti térség közigazgatási problémái kapcsán.

Tér és Társadalom 15. évf. 2001/3-4. 69-80. p.

gek növekedése, energiafelhasználás növekedése, környezet-terhelés növekedése. Ugyanakkor a nemzetközi összehasonlítás során a szociális vonatkozások, a megfizethetöség kérdése is komoly teret kap.

Melyek azok a megfontolások, amelyek részben Zegras (Zegras 2000), részben mások munkáiból kirajzolódnak?

- A várospolitika megfeleltetése a kihívásoknak (terület-felhasználás, multifunkcionális városrészek kialakítása).

- Integrált közlekedési rendszer kialakítása (tömegközlekedés, parkolás, forgalom-szabályozás, utak).

Mielött átfogóan megvizsgálnánk a fenti kérdéseket, vegyük számba a budapesti térségnek a közlekedés-politika szempontjából legfontosabb tényezőit, melyeket egy magyar szerzö cikke (Mándoki 2000) emelt ki.

\section{A budapesti térség kérdései}

A szakirodalom alapján (mindenekelött Monigl 2000a) közlekedési szempontból két alapvetö jellemzöje van a budapesti térségnek:

- A forgalom intenzitása növekszik.

- Az egyéni közlekedés (motoros) térnyerése a közösségi formákkal szemben.

Vizsgáljuk meg, hogy milyen hatással vannak ezek a folyamatok a térség közlekedésére, annak legfontosabb tényezőire, mennyire jelentenek problémát számukra, illetve mik ezen tényezök számára a problémák a jelen viszonyok között. Mándoki Péter idézett cikkében (2000) a közlekedési társulás hatásainak modellezéséhez felvázolja a helyi közlekedés legfontosabb tényezöit, érdekhordozóit: finanszírozók, üzemeltetők, tömegközlekedés utasai, egyéni közlekedés utasai, helyben lakók (környezetvédök). Egyetlen módosítást hajtottunk végre a fenti csoportokban, a kỏzlekedők két csoportját összevontuk, hiszen úgy véljük a két csoport közötti átjárhatóság egy nagyon fontos kérdés, vagyis ugyanarról a közlekedő népességröl van szó, amely egyik vagy másik eszköz-csoportot választja. Tekintsük át ezeket a tényezőket a mi kicsit általánosabb, sajátos szempontunkból.

\section{A finanszirozók}

Mándoki Péter számára a finanszírozók az állam és az önkormányzatok. Ezek a látszólag egyszerủ szavak a vizsgált térségben egy végtelenül bonyolult adminisztratív, felelősségi és érdekeltségi rendszert takarnak. Jól szemlélteti a helyzetet az északi híd ${ }^{4}$ kérdése, amelynek jelentősége messze a városon túlmutató, és amelyben az állam, a Főváros és az egyik kerület is meg tudott egyezni. Ám a másik érintett kerület számára fontosabbak sajátos szempontjai, sem hogy egy tarthatatlan közlekedési helyzetet legalább részlegesen orvosoljanak.

Az állam: A legfontosabb finanszírozó. Az elmúlt 10 évben hol aktívabban, hol kevésbé aktívan vett részt a konkrét kérdésekre adott válaszok megfogalmazásában 
Tér és Társadalom 15. évf. 2001/3-4. 69-80. p.

(lásd Lágymányosi híd $\leftrightarrow$ Galváni úti híd, 4-es metró 1998-2000stb.). Újabban a nagyobb beruházások megfenekleni látszanak, mert az állam, ahogyan a Főváros, a saját céljait a másik forrásaiból, azok felhasználásával kívánja megvalósítani a kompromisszumkészség teljes hiánya mellett.

A térségi, településközi közlekedésben már nem csupán pénzügyi, hanem jogi felelössége is van az államnak. Ennek megfelelően az állam a két, döntöen településközi közlekedésre szakosodott cégnek a tulajdonosa (MÁV, Volán).

A Fövärosi Önkormányzat: A második legnagyobb szereplöje a térség közszférájának. Akarata, célja világos: mindenképpen meghatározó tényezöje kíván lenni a térségnek, melynek azonban már a vâros határain belül is komoly akadályai vannak, még ha súlya elvileg fel is jogosítaná rá. A tízéves változatlanság a legfőbb vezetésben stabilitást és tapasztalatot biztosított számára. Tudatosan, szakmai tapasztalatok alapján igyekszik érdekeit érvényesíteni. Ellenfelei mások érdekeivel szembeni érzéketlenséggel vádolják.

A közlekedés-politika, a közlekedési rendszer vizsgálatakor kiemelten fontos szereplő a Fővárosi Önkormányzat, hiszen a fö közlekedési utak az ö felügyelete alá tartoznak, a BKV az ö tulajdona.

Kerületi önkormányzatok: Nagyon eltérỏ érdekek jelennek meg a kerületek között. Újabban két fontos csoportjuk látszik elkülönülni (külső és belső kerületek), noha a határok nem világosak, gyakran keverednek kifejezetten politikai szempontokkal. Érdekeltségeik inkább rövid távon fogalmazódnak meg, ahogy felelösségük is inkább ilyen. Általában erős széthúzás jellemzi a kerületeket, bár a fövárossal szemben többször is képesek voltak egységesen fellépni.

A külsö kerületek számára az agglomeráció a napi harcot jelenti a ,jó beruházásokért", a fóváros egésze szempontjából viszont nagyobb forgalmat, a közlekedés kiemelt célterületét. Ezek a tények külön hangsúlyt adnak annak a furcsa helyzetnek, amely a parkolásra jellemzö. A Föváros kezdeményezésére alakult parkolási társaságba bizonyos kerületek eleve nem voltak hajlandók belépni, mások a választások után léptek ki. Jelenleg kêt társulás müködik párhuzamosan. Egyik ösztönzi a másikat. Előfordul, hogy egy kerület fö közlekedési útján egyik, az abból nyíló mellékutcán egy másik társaság üzemelteti a parkolóorákat, így azok nem is kompatibilisek.

Pest megyei önkormányzat: A térség harmadik nagy tényezője. Szerepvállalása az elmúlt évek során lényegesen elmaradt valódi súlyától, ami talán abból is adódik, hogy a fővárossal ellentétben itt jelentős volt a vezetés fluktuációja. Rontja a megye pozícióit az is, hogy a Fővárosi Önkormányzatnál kisebb hatása van a települési önkormányzatokra, és felelősségi köre is lényegesen korlátozottabb. Nagyobb befolyást a térségi szerveződésekben (megyei és regionális fejlesztési tanács) képes elérni, ahol egyértelmủ a jogosítványa a megye településeinek képviseletére, és ezt erösíti a jelenlegi politikai konstelláció is.

Pest megye települési önkormányzatai: A megyében 184 önkormányzat volt Nagykovácsi szétválását megelőzően. Ahogy a fővároson belüli kiulönbségek legalább akkorák, mint az ország legszegényebb és leggazdagabb területei között, úgy 
Tér és Társadalom 15. évf. 2001/3-4. 69-80. p.

ez a megyére is igaz (északi és déli területek szemben a fövárossal határos nyugatidél-nyugati területekkel). A megye településeit a fövárossal szembeni arrogancia ${ }^{5}$ és a föváros közelségének messzemenőkig való kihasználása jellemzi, ahogy a fövárosi önkormányzatok számára sem igen léteznek partnerek a város határának másik oldalán. Stabil együttmüködés a fövárosi önkormányzatok valamelyike és a környező települések között alig van.

Tény, hogy a települések egy része igyekszik hagyományos karakterét óvni a beköltözőkkel szemben. Ezek az eröfeszítések a föváros közvetlen közelében reménytelenek, valójában gyengék az önkormányzatok eszközei a magán szférában zajló folyamatokkal szemben. Beköltözés-ellenes adópolitikával tudomásunk szerint egyetlen önkormányzat sem kísérletezett.

Bonyolítja a két térség (a főváros és Pest megye), illetve az egyes részszereplök kapcsolatát az, hogy jellemzỏen eltérỏ pártokból kerül ki a vezetésùk, ami rányomhatja az országos politika pecsétjét olyan helyi jelentőségü ügyekre is, amelyeknek semmi köze a nagypolitikához.

Összességében a térséget a teljes széthúzás jellemzi, holott a legtöbb kérdésben egyezségre lenne szükség. Nem hozott látványos eredményt az Agglomerációs, majd a Központi régió Fejlesztési Tanácsának a megalakulása sem, ahol a szereplöknek legalább egy asztalhoz kellett ülniük. Ebben a politikai okok mellett szerepe van a nagyon eltérő érdekeknek és a felismerés hiányának, miszerint a föváros legalább annyira rá van szorulva a környékére, mint az a fövárosra. A politikusi interjúk alapvetöen két attitüdröl tanúskodnak: az egyik szerint a másik fél nem létezik, de legalábbis nincs jelentősége (a Főváros), a másik szerint a másik fél minden probléma oka (Pest megye).

A lehangoló összkép ellenére a térség közigazgatása és közszolgáltatásai működnek, és ez sok területen éppen a müködő együttmüködéseknek köszönhetö. A legsikeresebb együttmüködésként egy volt fópolgármester helyettes az infrastruktúra (víz-szennyvíz) területét nevezte, legutóbb a szemétszállítás-elhelyezés területén valósult meg egy nagyobb beruházás (a pusztazámori szemétlerakó). A közlekedés területén is van valamekkora együttmüködés, de ezt a területet elsösorban az együttmüködés hiánya jellemzi. A BKV járatai kijárnak a városon kívülre (tudomásunk szerint nem szünt meg ilyen járat, sőt egyes szakemberek szerint ezek a nyereséges vonalak közé tartoznak), de folyamatos a panasz mindkét oldalról. A föváros a városkörnyék településeinek fokozott önkormányzati részvételét követeli a finanszírozásban, miközben a másik oldal igyekszik ezt elhárítani. Budakalász polgármestere egy ízben azt vetette fel, hogy a BKV nem adózik a településen kialakított HÉV szolgáltatás után.

Az ellentétek ellenére a fơváros számol az agglomerációval. Valószínúleg politikai okokból igyekszik annak szerepét elkenni, de az agglomerációs ÁRT-vel kapcsolatban például markáns álláspontot fogalmazott meg: építési - beruházási - teriilet-átminősítési moratórium. Az agglomeráció és Pest megye szempontjából, ahogy az a megye egyik alelnökének szavaiból kitünik, éppen a közlekedés a legfontosabb kérdés. Azzal vádolja a fövárosi vezetést, hogy a politikája „,a City” védelme. Vég- 
Tér és Társadalom 15. évf. 2001/3-4. 69-80. p.

eredményben azonban a megfogalmazott vádak annak a közlekedés-politikának szólnak, amely a városi közlekedés fenntarthatóságára törekszik, gyakorlatilag megfelel a szakirodalom által is javasoltaknak, részben immáron restriktív eszközökkel is. Ennek a politikának része, hogy a város központja felé irányuló sávokból kevesebb van, mint ahány a nagykörúton belüli területre visz be, hogy a közlekedési lámpák úgy vannak beállítva, hogy az autók gyorsabban tudják elhagyni a belső részeket, mint ahogyan bejutnak, illetve a parkolási rendszer, amely az eredeti elképzelések szerint a város egészére kiterjedne.

Az ingatlanpiacon keresztül a várost fojtogató agglomerációval szemben a föváros közlekedési kártyáját játssza ki. Nyilvánvaló azonban, hogy mindkét területen együttmükoòdésre lenne szükség. A rendszerváltás utáni piacgazdasági feltételek és a régiók Európája, amely felé az ország készưll, elemi érdekké teszik a Központi Régió befolyásos tényezői számára, hogy e térségben, amelynek jelentősége messze a határokon túl nyúlik, megvalósuljon az egyưttmüködés (Matolcsy 1998; illetve közlekedési szempontból Erdősi 2000).

\section{Az üzemeltetök}

Mint ismeretes, a fel-felbukkanó kisebb magánszolgáltatók ellenére (vagy mellett) a térségben három domináns társaság müködik. Ezek közül kettő állami (MÁV, Volán) és egy önkormányzati (BKV) tulajdonban van. Idöről időre ez utóbbi is kap állami támogatást, de döntően (50\%-ot meghaladó mértékben) önkormányzati forrásokból müködik, jegyár bevételei ettől elmaradnak. Ellentmondásos, hogy a jegyárak emelkedésének mértékét a Kormány hagyja jóvá, holott a keletkező veszteségekért nem terheli semmilyen felelósség. A jegyek árában a MÁV és a másik két társaság között van nagyobb különbség, ugyanakkor mindenképpen az a sokkolóbb, hogy egy buszmegállóban a várakozók nem szállnak fel a többé-kevésbé üres VOLÁN buszra, megvárják a tömött BKV járatot, amelyre a bérletük szól ${ }^{6}$.

Monigl János (2000a) elemzése a BKV kapcsán arra mutat rá, hogy a közlekedési cég mutatói, pénzügyi szempontból, javulnak. Bár utas-teljesítménye 20\%-kal csökkent, a 28\%-os ráfordítás-csökkenés mellett a cég üzemi teljesítménye csupán $18 \%$-kal lett kevesebb. Az áttörést a budapesti térség közlekedési rendszerében a fövárosi közlekedési társulás megalakulása jelentené. Ezt tulajdonképpen minden szereplő elismeri. Ennek akadályai, úgy tủnik, nem az önkormányzatok, illetve az önkormányzatok és az állam közötti villongások, hanem a három társaság eltérő árképzési, támogatási rendszere, a menetrendek összehangolásának nehézségei, végeredményben az, hogy ki és milyen mértékben finanszírozza a szövetség létrejöttét, mủködését. A szakértők már részletekbe menően kidolgozott tervezetekkel rendelkeznek (Monigl 2000a). 
Tér és Társadalom 15. évf. 2001/3-4. 69-80. p.

\section{A tömeg- és egyéni közlekedés utasai}

A közlekedök, mindenekelött nagy tömegben, tehát pillanatnyi céljaiknak, lehetöségeiknek megfelelően választják a legolcsóbb, leggyorsabb, leghatékonyabb és legkényelmesebb eszközt. A döntésekröl, nem kizárólag közlekedési vonatkozásban, a korlátozott racionalitásról szóló hosszú szakirodalom szól, a közlekedők összességében mégis megtalálják az adott körülmények között optimális útvonalat, kombinációt ${ }^{7}$.

Monigl János részletesen elemzi az okokat, amelyek a városi közlekedés átalakulását jellemzik (Monigl 2000a):

- Csökkenő vállalatméret, intenzívebb kapcsolatrendszer ;

- A belső városrészek funkcióváltása (bankok, szolgáltatások megjelenése);

- A gépkocsi-ellátottság javulása;

- A tömegközlekedés színvonalának romlása és árainak emelkedése;

- A modal split romlása a tömegközlekedés kárára.

A fenteikböl az tủnik ki, hogy komplex szemléletủ térségi közlekedési rendszer kidolgozása szükséges, olyan körülmények között, amikor ez a városon belül is csak részlegesen sikeres, többnyire ott, ahol egyetlen szereplő hatásköre (2. ábra).

\section{A helybenlakók, környezetvédök}

Mándoki Péter (2000) azonosítja a két csoport érdekeit. Ezzel nem értünk egyet, mert a lakosság konkrét problémák megoldását keresi, míg a környezetvédők a „világ hosszú távú érdekeit” képviselik. A lakosság elviselhető életfeltételeket, aminek mindenképpen része a közlekedés képessége, tehát egyfajta valóságot, míg a környezetvédők elveket képviselnek. A lakosság érdeke az, hogy az általa lakott terület közvetlen közelében jelentős átmenő forgalom alakuljon ki. A környezetvédők által képviselt fenntartható jövő szempontjából a közlekedés, annak korlátozása, közösségi formák felé terelése kulcskérdés. Az egyezés tehát az, hogy a lakosság a saját lakhelyén környezetvédö, a másokén viszont könyörtelenül képviseli akár a közlekedés képességének szabadságát is. Két nagyon fontos példa jellemezheti a helyzetet. Az elsỏ esetben a lakosság, a másodikban környezetvédök voltak a főszereplők, mindkettő a föváros közlekedésének fontos pontjain zajlott.

Az első az 1990-es évek elején, a Lágymányosi híd budai levezetésének kérdése, amely most példátlan módon a hídfőnél 90 fokos kanyarban folytatódik. A híd vonalában egy lakótelep található, amelynek lakói sikerrel akadályozták meg a hídról lejövő forgalomnak az M1-M7-es autópálya közvetlen elérését. A közlekedési hatások mellett külön említést érdemel, hogy a forgalom így most más lakótelepek mellett halad, vagyis a helyzet nem lett jobb, csak másokat szennyez. A mostani nyomvonal, az Andor utca lakói is tiltakoztak, de ezúttal a városvezetés határozottabb volt, és a lakások felvásárlását ajánlotta fel. 
Kovács Róbert : Gondolatok a közlekedés és szervezeti kapcsolatai kérdésköréröl a budapesti térség közigazgatási problémái kapcsán.

Tér és Társadalom 15. évf. 2001/3-4. 69-80. p.

TÉT XV. évf. 2001 - 3-4

Gondolatok a közlekedés ...

\section{2. ÁBRA}

Budapest és környéke személyszállitás intermodális rendszerének struktúrája (The Structure of Intermodal System of Transit in Budapest and Its Surrounding)

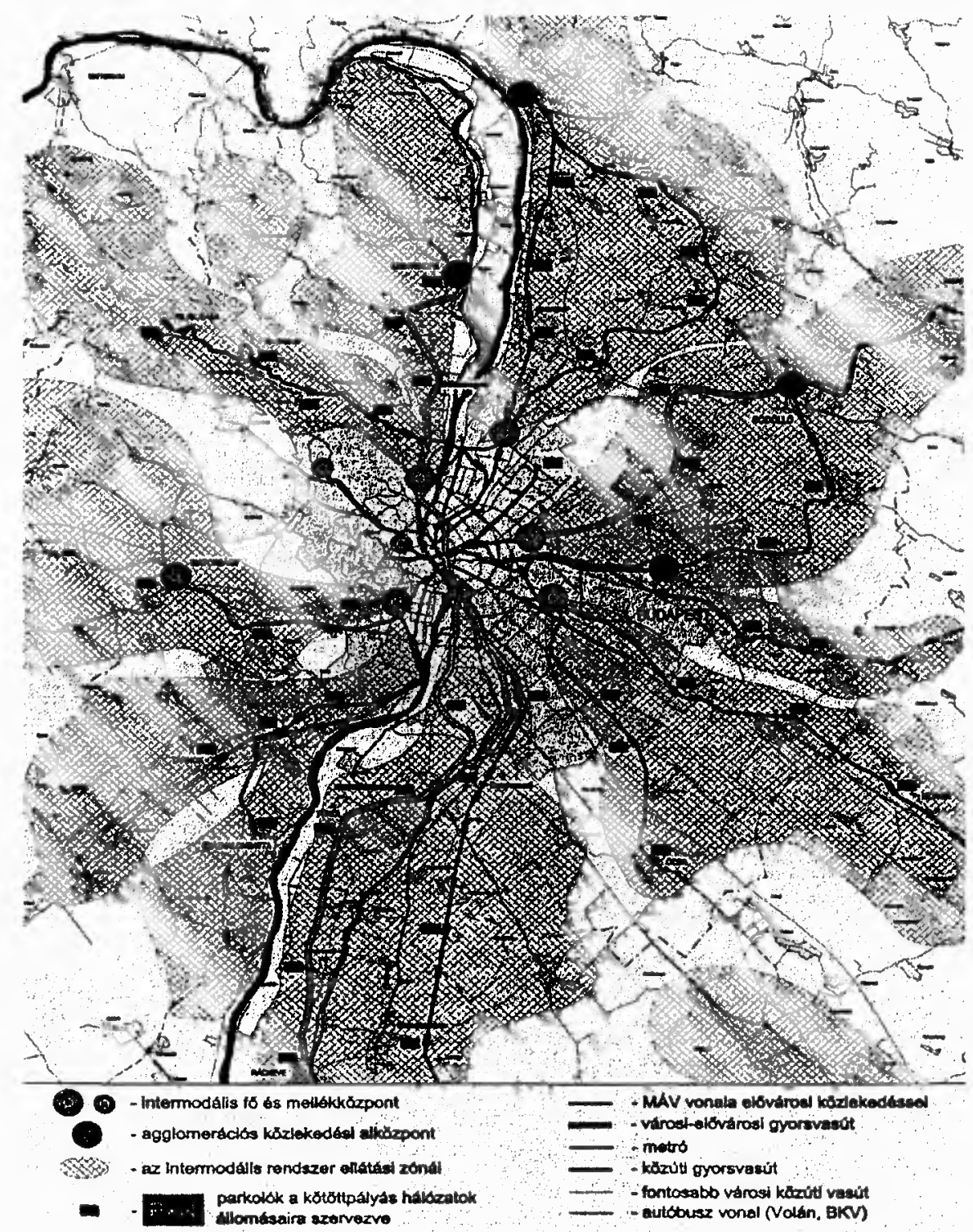

Forrás: Budapest városfejlesztési koncepciója 1999. 2000, VIII-9.

A második példa egy gyakorlatilag élö víta. Az M0-ás autópálya északi hídjának építését a környezetvédök felfüggesztették, tekintettel arra, hogy a híd egy környezetvédelmi szempontból kényes területet érint (Szentendrei-sziget déli része). Ebben az esetben két kérdés is felmerül: vajon mi aggályosabb környezeti szempontból, ha egy hídon folyamatos haladással átkelnek a gépjármüvek, vagy folyamatos 
Kovács Róbert : Gondolatok a közlekedés és szervezeti kapcsolatai kérdésköréröl a budapesti térség közigazgatási problémái kapcsán.

Tér és Társadalom 15. évf. 2001/3-4. 69-80. p.

dugókban állva szennyezik a levegőt. Vajon okoz-e akkora kárt a kömyezetben a hídon áthaladó forgalom, mint amennyivel a városi környezetet és a városlakók egészségét rombolja.

\section{Megoldási alternatívák a budapesti térségben}

$\mathrm{Az}$ áttekintett szakirodalom a városi térségek közlekedési problémáinak elemzése kapcsán elsősorban a centrumra, a városi közlekedés-politika teendőire koncentrál. Ennek értelme, összevetve a jelenlegi hazai településfejlődési tendenciákkal, az, hogy a magyarországi szuburbanizációs folyamatok esetében, még a legkifejlettebb változatban is a városmag és a várost körillölelö települési gyürú közötti kiegyenlítődő szívóerố mellett a városmag dominanciája a jellemző". Ugyanakkor Bergék modelljének (Berg et al. 1982) és általában a városfejlődés-elméleteknek az elfogadása arra sarkall, hogy nagyobb figyelmet kell fordítani a funkcionális városi térség gyürủ részének problémáira is.

Monigl János úgy fogalmaz, hogy a város problémáinak, a våros élhetőségének kérdése a belső városrészek állapotának, élhetőségének a problémája, ez „döntő mértékben befolyásolja" a văros egészének életét, müködését (Monigl 2000a, 9). Számára a belső területek problémáinak megoldásában meghatározó a kőzlekedés kérdése: „Budapest közlekedési problémáinak súlypontja a belsỏ területeken van, a helyzet javítása azonban döntően a külső területek, és az agglomerációs környék kapcsolatainak célzott javításával érhetỏ el." (Monigl 2000a, 10) Monigl János szerint a fövárosi közlekedéspolitika céljainak a következőknek kellene lenniük:

- Közlekedési kapcsolatok biztosítása;

- Belsó terulletek tehermentesítése;

- A környezetromlás fékezése;

- A közlekedési rendszer hatékonyságának növelése;

- Hozzájárulás a finanszírozáshoz (Monigl 2000a).

A térséggel foglalkozó közlekedési szakemberek számára az agglomeráció mindenekelőtt többletforgalmat jelent, amelyet részben a városon kívül kell tartani, részben pedig minél nagyobb arányban a közösségi közlekedés eszközei felé kell terelni. A közösségi közlekedés vonzereje növelésének nélkülözhetetlen, de önmagában nem elegendỏ eszköze a Budapesti Közlekedési Szövetség (BKSz) megalakítása (Mándoki 2000; Monigl 2000b). A BKSz megalakítása ki kell, hogy egészuiljön részben „puha” (környezeti érzékenység növelése, környezetbarát technológiák elterjesztése, tervszerủ terület-felhasználás, motorizált egyéni közlekedés visszaszorítása forgalomszabályozással, üzemanyagadókkal), részben „kemény vagy restriktív" (motorizált egyéni közlekedés fokozott visszaszorítása sebességkorlátozással, útadókkal, gyalogosővezetekkel, szigorított károsanyag-kibocsátási normák) közlekedés-politikai eszközökkel (Mándoki 2000). Ezek csupán együtt jelentenek megfelelő ösztönzést az egyéni (motorizált) eszközökkel szemben, a közösségi közlekedés irányába. A cél azoknak az externáliáknak a minél teljesebb körủ megfizettetése, amelyeket az egyéni (motorizált) közlekedés okoz, és az, hogy az így megszer- 
Tér és Társadalom 15. évf. 2001/3-4. 69-80. p.

zett forrásokat minél nagyobb arányban a közösségi közlekedés versenyképességének javítására fordítsák.

Budapest városfejlesztési koncepciója lényegében a fenti szakmai szempontokat figyelembe veszi, sőt egyik készítője egy összefoglaló cikkében ki is emeli az agglomerációs gyürủ felé magas színvonalú kötöttpályás kapcsolatok létesítésének szükségességét (Molnár 2000).

Végezetül azt gondoljuk, hogy az áttekintett szakirodalom két kérdést nem vagy csak felületesen érint, holott a jelen tanulmány olvasójában, mint ahogy szerzőjében is, hiányérzetet hagyna, ha nem érintenénk. Ezek a demokratikus átalakulás hatásai a közlekedési fejlesztésekre, ami csak részlegesen érinti az általunk vizsgált kérdést, és a közösségi, tulajdonosi összhang megteremtésének fóruma, ami akár az elöbbi egy másik aspektusának is tekinthetô, ugyanakkor a tanulmány talán egyik legfontosabb kérdése.

Szemben a rendszerváltást megelőzỏ bürokratikus rendszerrel, ma már nem elég szakmai szempontból optimálisan megalkotott városi - térségi közlekedésfejlesztést megvalósítani, hanem arra is szükség van, hogy ezt a lakosság elfogadja, és a fejlesztések részét képezze a hátrányosan érintettek megfelelö kompenzálása. A jó példa a pusztazámori eset lehet, a rossz példa pedig a Lágymányosi híd budai hídfóje, mint örök mementó. Csak reménykedni lehet, hogy a kettő között eltelt idő a fejlődés irányát is mutatja.

A lakossági csoportok közötti konszenzus megteremtése mellett a politikai szinten belüli egyeztetések (intézményesült) fóruma is elengedhetetlen. Teljesen világosan látszik az áttekintett közlekedés-politikai kérdések alapján, hogy már ebben a pillanatban sem lehet Budapesten úgy közlekedés-politikát készíteni, hogy ne az agglomerációban kezdjük. Ez viszont olyan hatásköri és érdekeltségi kérdéseket vet fel, amelyek ma kezeletlenek, és véleményünk szerint a BKSz sem nyújt majd megfelelö megoldást, hacsak nem ruházzák fel közigazgatási, hatósági jogosítványokkal. Ez utóbbihoz azonban ebben a pillanatban sem a szükséges konszenzus, sem a gondolat érettsége nincs meg. A BKSz a jelenlegi tervekben elöször mint tarifaszövetség alakulna meg, innen pedig nagyon hosszú út vezet valamilyen hatósági jogokkal felruházott önkormányzati jellegủ testületig.

\section{Jegyzetek}

${ }^{1}$ Az első bejelentések valamikor az 1990-es évek kơzepére, 3. negyedének elejére tehetớk, miközben ma, mintegy fél évtizeddel később, még mindig jövő időben beszélnek róla az illetékesek.

2

A népességnövekedés egy-egy település esetében azért szembeơtlö, mert az ország népessége hosszú évek óta csőkken. A konkrét esetekben is a növekedés szinte kizárólag a vándorlási többlet hatása, amely ơnmagában is az említett települesi folyamatokra utal.

${ }^{3}$ Mándoki Péter az egyéni / tömegközlekedés externális hatásainak elemzésekor hasonló problémát fejteget (Mándoki 2000). 
Kovács Róbert : Gondolatok a közlekedés és szervezeti kapcsolatai kérdésköréröl a budapesti térség közigazgatási problémái kapcsán.

Tér és Társadalom 15. évf. 2001/3-4. 69-80. p.

80 Kovács Róbert TÉT XV. évf. 2001

4 Az Árpád hídtól északra elterülö hatalmas, sủrūn lakott térség (több lakótelep mindkét oldalon és felkapott agglomerációs övezetek Pest - budai összeköttetés nélkül).

${ }^{5}$ Látszólag nem helyén való egy maximum néhány ezres település és egy közel kétmilliós város kapcsolatában a kisebbik arroganciájáról beszélni. A szóhasználatot részben a kölcsönỏsség, részben az a tény indokolhatja, hogy a kicsik így ellensúlyozzák, kompenzálják fưggőségúket, illetve így próbálják tompítani, elkerỉlni a lakosaik által igénybe vett fövárosi szolgáltatások (pl. közlekedés) költségeinek megtérítésére vonatkozó fövárosi igényeket.

${ }^{6}$ A társaságok kỏzỏtti tarifa-kapcsolatokra jó példa az, hogy a fóvárosba intercityvel érkezók az utazás napján ingyen közlekedhetnek a BKV járataival, vagyis a vonatjegy tartalmazza a fóvárosi tỏmegközlekedés költségeit.

Ez nem mond teljesen ellent annak a nem verifikált tudományos tételnek, miszerint ha a gépkocsi felkerülne a tiltott drogok listájára, az sem csökkentené népszerüségét.

Ezt érdemes Erdősi Ferenc nyomán azzal a ténnyel is megerósíteni, hogy a kisebb cégek szállítási igényeihez kevésbé igazođnak olyan nagy nem közúti szállítók, mint a MÁV.

${ }^{9}$ Bergék (Berg et al. 1982) modelljếnek kitételei a hazai viszonyokra alkalmazva.

\section{Irodalom}

Berg, L. van den-Drewett, R.-Klaasen, L.H.-Rossi, A.-Vijvetberg, C.HT. (1982)-Urban Europe I: A Study of Growth and Decline.

Budapest városfejlesztési koncepciója 1999. (2000) Budapest.

Enyedi Gy. (1988) A városnövekedés szakaszai. Akadémia Kiadó, Budapest.

Erdósi F. (1991) Kommunikáció és térszerkezet. Akadémiai Kiadó, Budapest.

Erdösi F. (2000) Európa közlekedése és a regionális fejlödés. Dialóg Campus, Budapest-Pécs.

Kovács R. (1999) A szuburbanizácio hatása az önkormányzatokra. Kandidátusi értekezés és válasz az opponensi véleményekre. Kézirat.

Matolcsy Gy. (1998) A budapesti régió lehetséges szerepe a regionális együttmüködésben. Kutatási zárótanulmány. Magyar Tulajđon Alapítvány - Privatizációs Kutatóintézet, Budapest.

Mándokỉ P. (2000) A térségi személyi kỏzlekedés fejlesztésének infrastrukturális hatásai. - Magyar I. (szerk.) Városi és térségi közlekedés. MTA, Budapest.

Molnár L. (2000) A közlekedés szerepe Budapest fejlódésében. - Budapesti Negyed. 28.

Monigl J. (2000a) A Budapesti Közlekedési Szövetség létrehozásának feltételei. - Magyar I. (szerk.) Varosi és térségi közlekedés. MTA, Budapest.

Monigl J. (2000b) A fővárosi közlekedéspolitika elveinek és eszközrendszerének pontosítása. - Magyar I. (szerk.) Városi és térségi közlekedés. MTA, Budapest.

Perczel Gy. (szerk) (1996) Magyarország társadalmi-gazdasági fóldrajza. ELTE Eötvős, Budapest.

Zegras, C. (2000) A városi közlekedés. - Enyedi Gy. (szerk.) Magyarország településkörnyezete. MTA, Budapest.

\section{IDEAS ABOUT THE QUESTION OF TRANSPORTATION AND ITS ORGANISATIONAL CONNECTIONS IN THE CASE OF THE ADMINISTRATIVE PROBLEMS OF BUDAPEST AREA}

\section{RÓBERT KOVÁCS}

In the study the actor wants to put the transportation problems of Budapest Agglomeration into a multidisciplinary aspect on the basis of works and ideology of transportation experts. It analysis the factors and interests of transportation and transportation policy in the region of Budapest and its surroundings. After that it draws the most important transportation policy conclusions by clashing the theoretical and the particular knowledge concerning the region. 